\title{
Connection among Water, Agriculture, and Human Rights, and Its Concerns in Bangladesh
}

\author{
M Anwar Hossen* and M Rafiqul Islam \\ Department of Sociology, University of Dhaka, Bangladesh \\ *Corresponding author: M Anwar Hossen, Professor, Department of Sociology, University of Dhaka, Dhaka

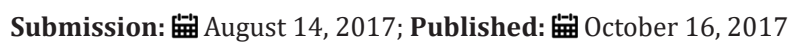

\begin{abstract}
The Ganges Basin communities in Bangladesh are entirely dependent on the Ganges River flow for their agricultural production; river flows determine whether most people will have access to employment, food, education, housing, and health care. For the vast majority of people in this region, this production includes the ability to match cropping strategies effectively to river water flows during both rainy and summer seasons, to utilize a variety of common property resources, such as fisheries, and to augment subsistence food production with some shareholder activities, and agricultural employment. However, this pattern of agricultural production is increasingly undermined by government driven processes of water and agricultural development, many of which, now, follow explicitly neoliberal economic agendas. Based on this argument, this paper explores a research question: what are the concerns for the government's water and agricultural policies in the connection among water, agriculture, and human rights at Chapra in Bangladesh? To address this question, this research paper focuses on water and agricultural development approach based on my PhD fieldwork experiences in 2011-12 at Chapra of the Ganges Basin in Bangladesh. The findings of the paper point out that the majority of the people living in Chapra, as in many other Ganges Basin communities, depend on their own agricultural production to protect the human rights, and this production, in turn, depends on water resources that are, increasingly, under the control of elite interests and a centralized state bureaucracy. The paper argues that only the inclusion of community voices over water policy formulation and implementation processes can protect their human rights in Bangladesh.
\end{abstract}

\section{River Water and Human Rights: Bangladesh Context}

Bangladesh encompasses 147, 570 square kilometers and has a population of 150 million [1]. About 99 percent of people speak Bengali as their mother tongue and 90 percent of people are Muslims [2]. Total households are 3.2 million with an average household size of 4.4 people [1]. Population density is 1015 per square kilometer. More than 75 percent of the people live in rural areas [3]. There is no need for permission from government to build rural housing facilities. About 87 and 61 percent of rural people do not have access to a daily newspaper and television, respectively. They do not have internet access and most of them do not have electricity. In rural Bangladesh, 66 percent of people use unsafe toilet facilities and 87 percent of people use traditional cooking fuel like straw. Among the rural people, literacy rates are 52 percent, and infant mortality rates are 38 per 1000 [1].

Bangladesh is a delta country with major floodplain agroecological systems in addition to hill and terrace land areas (Map 1). The Ganges-Brahmaputra Basin (GBB) flow develops these systems based on the 57 international and 310 local rivers [4]. About 94 percent of water flow originates from outside of Bangladesh, in India [5]. More than one million of 14 million hectare lands are covered with local water bodies like wetlands, ponds, and rivers [4]. The GBB flow is crucial to basin communities' human rights protection as it transports siltation to local cropland, produces

local fisheries and replaces exhausted topsoil every year. In 2010, the Ganges Dependent Area (GDA) populations in Bangladesh were 70 million, about 45 percent of the people in Bangladesh [4,6].

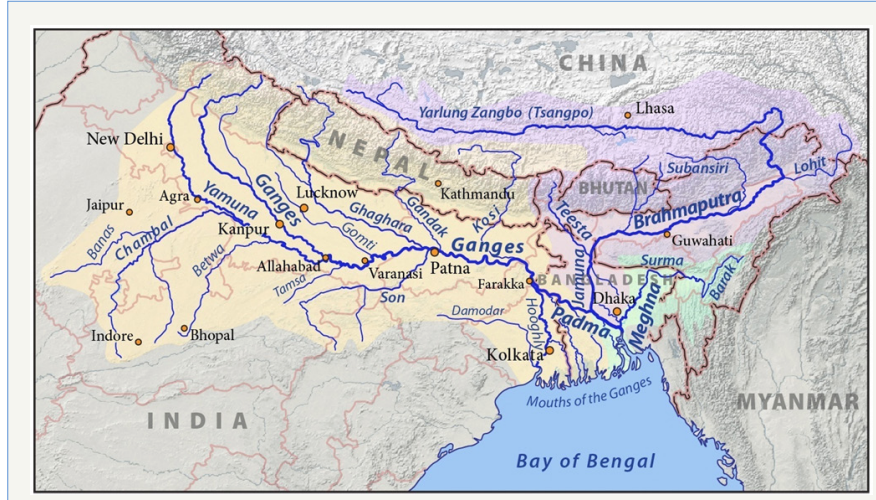

Map 1: The ganges brahmaputra basin in India, China, Nepal, Bhutan and Bangladesh.75 [34].

My fieldwork site, Chapra, is connected to the Ganges Basin through the Gorai River. This village falls under the authority of the Chapra Union Council at Kushtia District in Bangladesh and is about 236 kilometers away from the Farakka Barrage and about 11 kilometers downstream from the Hardinge Bridge in Kushtia. Forty-four community members attended the focus group 
meeting including seven rich farmers, nine intermediate farmers, twelve marginalized farmers and sixteen landless agricultural day laborers. Four in-depth case study respondents were selected from the focus group respondents to explore voices of the different groups of people. Their pseudo-names, Tanvir, Tofajjal, Joardar and Billal are used here to protect their privacy and to ensure their representation. All of the respondents live in Chapra and receive socio-ecological services from the Gorai River for generations.

These bonds between Chapra community and the river flow are the foundation for human rights protection that includes agricultural production, employment, education, food, housing and health care. Agricultural practices are seasonally divided into the kharif 1 , kharif 2 and robi corresponding to the summer, rainy and winter seasons respectively. The ecosystem provides agricultural resources such as fertilizer from siltation, algae and water hyacinth and indigenous seed production. Community people get employment opportunities in traditional seed cultivation and preservation, plowing, fertilizer making, irrigation and fisheries. Many of them collect water borne wild vegetables like water lily and the hyacinth bean for consumption. They enjoy traditional cultural practices like nouka bice, or boat racing, based on the basin flow. Their traditional knowledge regarding agricultural and cultural practices is essential and integral to their human rights protection. Only the secured level of river water rights is the prerequisite for this human rights protection.

The United Nations (UN 2002:3) states that “...water is necessary to produce food (right to adequate food) and ensure environmental hygiene (right to health). Water is essential for securing livelihoods (right to gain a living by work) and enjoying certain cultural practices (right to take part in cultural life)". This UN statement is relevant to the basin communities at Chapra whose access to education, health care and decent housing always depend on their ability to care for domestic animals, fish and gather wild vegetables, activities, which, in turn, depend on the health of the local ecological system. These socio-ecological aspects of human rights are relevant to 1948 Universal Declaration. Article 22 of this declaration incorporated social security, social and economic rights as human rights. Article 23 of this document defined employment opportunities, equal wage, and trade union right for a decent family life. Article 25 focused on standards of living and well-being that specified food, clothing, housing, health care, and social services. Articles 26 and 27 included education and cultural rights as human rights. Moreover, the 1997 UN Watercourse Conventions describe these human rights as the vital human needs.

In 1966, the UN Covenants of Economic, Social, and Cultural Rights identified water as a human right in securing foundational rights to life. In 2002, the UN committee on Economic, Social and Cultural Rights recognized the right to water in articles 11 and 12 specified major guidelines for protecting basic water rights of drinking, sanitation, and irrigation without any discrimination [7]. This water right should be "sufficient, safe, acceptable, physically accessible and affordable for personal and domestic uses" (United Nations 2002). This right based approach proclaimed, "(w) ater should never be used as an instrument of political and economic pressure" [8]. Articles IV, V, and V (III) of the Helsinki Rules (1966) and article VI of the UN 1997 Watercourse Convention also secured this right.

However, the government in India and Bangladesh follows their own understanding about water and agricultural development in the Ganges Basin and ignores the river basin community voices. The central government in India, for instance, established the Farakka Barrage unilaterally on the Ganges Basin, reducing flows to agricultural communities in Bangladesh at critical times in their cropping cycles. The central government in Bangladesh has been unable to restore this flow to a sufficient level and subsequently, has followed top-down water management approaches such as the Gorai River Restoration Project (GRRP) to overcome the Farakka effects. This project, however, did not take into account the traditional cropping patterns of small-holder farmers and those farming households, which constitute the vast majority of the population in the region, and who now find themselves more and more vulnerable to livelihood failures. Those failures result in what are, arguably, human rights abuses, since they mean that many households are now unable to secure basic human rights, as defined by the United Nations, to food, water, education, housing, and health care.

This human rights approach to water argues that water development approach generates marginalization by treating nature as a commodity to promote the business interests of corporate elites; thus marginalized basin communities are deprived of their rights [9]. The discourse of modernization builds on Enlightenment ideals and uses a "seductive mix of words" for promoting their own agendas (Cornwall and Brock 2005) and buzzwords, such as "what is good for capitalist business is good for the country" [10]. Based on this approach, governments turn increasingly to scientific knowledge rather than local knowledge and attempt to exercise more control over community resources $[11,12]$. A basic question about the government domination of scientific research "is it not the State that has dreamed of a "science-based politics," a monster in whose name so many crimes have been committed?" [13]. Water and agricultural modernization for poverty reduction and economic growth are major causes of local community marginalization.

Das and Poole (2004: 8) pointed out the negative consequences of bio-politics:

- Indeed, marginalization is a powerful technique of power precisely because the margin is both a real place where roads do not penetrate, commodities seldom reach, and school barely exists, and a discursive and ideological position from which people learns how to speak about things like justice to the state and among themselves [14].

This modernization as an ideological project speaks for its promoters and the 'others' encounter survival challenges which is visible in Bangladesh. This politics of modernization on water resource development follows a specific political economy based on a specific power structure and economic system [15]. The 
government in assistance with international development agencies develops nature as a political subject based on the bio-politics of development, which began with the historical trajectories of modernization and post-modernization [16]. Latour [13] focused on the political ecology of nature that describes the Western root of power that promotes top-down domination over the least developing countries. Based on this domination, the central Government of India is successful in its colonizing of the Ganges Basin based on this power-politics. The central government in Bangladesh fails to overcome India's domination and colonizes community resources. For this purpose, the central government reformulates rules and regulations regarding local resource management that are consistent with modernization and postdevelopment agendas. This bio-politics helps the powerful countries to control the Ganges Basin water, which is responsible for human rights concerns over local marginalized communities in Bangladesh. To get deeper understanding of this human rights argument to water, it is important to describe hydro-politics in South Asian countries.

\section{The Ganges Basin Hydro-Politics and Ecosystem Concerns}

The Ganges-Brahmaputra Basin (GBB) originates from the Himalayan Mountains, flows through several South Asian countries and ends in the Bay of Bengal. The two major branches of the Ganges headwaters in India are the Alakananda and Bhagirthi Rivers that flow south from the Himalayas. Another large tributary, the Rama Ganga, originates from the Himalayan Mountain range in Nepal and meets the Ganges flow before merging with the Yamuna (Allahabad), the Gomati and the Ghagra Rivers in India. These branches of the Ganges connect to the three other Nepalese tributaries: the Sarda, the Karnali-Rapti and the Gandak-Kosi Rivers [17]. The Brahmaputra Basin originates from the northern slope of the Himalayas in the Kailash range and flows eastward for about 900 miles in China where it is known as the Tsangpo. The southward course of the Tsangpo River moves to the Sadiya frontier in India where it divides into three major tributaries in Arunachal Pradesh: Dibang, Lohit and Subansiri that flow through Bangladesh to the Bay of Bengal [18]. These basin flows dominate hydrological patterns, ecological systems and floodplain livelihood practices in Bangladesh.

Historically, the Ganges Basin is the site of one of the first ancient civilizations, dating to $2500 \mathrm{BCE}$ and located at Mahasthangar in Bangladesh and Gaud in West Bengal, India [19]. The basin was referred to as the "Paradise of the World" and was the major source of wealth for the Mogul Empire and later the British Empire [20]. Local farming communities thus, have been subject to interference for centuries though never on the scale experienced today by communities in Bangladesh. The British Colonial Government in India constructed 2,298 miles of canals and distributaries as part of the upper Ganges Canal project in 1854 and used them to irrigate 1.2 million acres of croplands. After independence in 1947, the government of India constructed a series of large barrages and diversions on the Ganges for irrigation and flood control purposes. Only after 1975, however, when the government constructed the
Farakka Barrage did this type of large-scale intervention in Ganges Basin hydrology have a major direct impacts in Bangladesh [21,22].

Based on this water management approach, political leaders in India manipulate Hindu nationalist sentiments sand foresee the dream of becoming a superpower (e.g. Kochhar-Lindgren 2013). This approach provides political parties with opportunities to win government power [23]. Based on this power, the Government of India had once planned to provide hydropower for the country's entire population by 2012. For this purpose, India built 4,300 dams by 1994 and is considered as one of the major dam building countries of the world [24]. This dam dependent water management began under the Nehru Government in 1947 and the recent National River Linkage Project (NRLP) is simply its most recent expression. To control the GBB, the country follows a hydro-hegemonic approach throughout South Asia [25]

The government of India unilaterally built the Farakka Barrage on the Ganges in 1975; about 17 kilometers upstream of the Bangladeshi border [26]. Successive governments of Pakistan failed to resolve the Farakka dispute from 1947 to 1971 because of India's non-cooperation [5]. Bangladesh's independence from Pakistan in 1971 signaled the beginning of a new era of conflict linked to the Ganges Basin management. The governments in India and Bangladesh agreed to operate the Farakka Barrage in 1975 for a forty days trial period to avoid conflict (Swain 1996:1991). After this trial period, India continued the water diversion unilaterally from the Ganges [27]. Swain [28] argued that "the construction of these huge projects has damaged the local environment and the diversions of water upstream have brought ecological disaster and political tension to downstream areas". To reduce tensions with Bangladesh, India established the bilateral Indo-Bangladesh Joint River Commission (JRC) in 1972, excluding China, Bhutan, and Nepal. To date, the JRC has failed to produce any major success due to lack of government cooperation and trust [29]. India and Bangladesh have never experienced a period of trust and reliability over the Ganges Basin management [23,30,31].

After President Mujib's assassination in 1975, the Zia Government tried but failed to negotiate with India. Consequently, president Zia sought international assistance in 1976 from the Istanbul Islamic Foreign Ministers' Conference, the Non-Alignment Movement (NAM) and the United Nations [32]. However, none of these initiatives were successful because of India's hydro-politics. In 1977, both countries signed an interim treaty for five years. President Zia was assassinated in 1981 before the treaty ended and Ershad, an army general, became the next President. India and Bangladesh signed two memoranda of understanding in 1983 and 1985 but the Ershad Government failed to make any real progress on the Farakka dispute, neither did the subsequent government under Khaleda Zia (1991-96). Under the Hasina Government (19962001), a proponent of Bengali nationalism, a treaty was signed on 12 December 1996 for a thirty-year period. This treaty, in theory, secures minimum water flow during the khora, or dry season, from January 01 to May 31 in the Ganges Dependent Area (GDA) in Bangladesh. However, in reality, the 1996 Ganges Treaty failed 
to make any positive outcomes. Verghese [33] noted, "Bangladesh is still unable to use its share of Ganges Treaty releases gainfully during the lean season in the affected SW (South-West) Region... does not permit any inflow after a certain stage in the recession of the Ganges flood". The average basin flow was 2360 cubic feet per second (cusecs) during the summer season in 1970 but only 927 cusecs in 1980 at the Hardinge Bridge Station in Bangladesh just above the Gorai River (Figure 1). This flow further reduced to 828, 766 and 743 cusecs in 1990, 2000 and 2010 respectively [34].

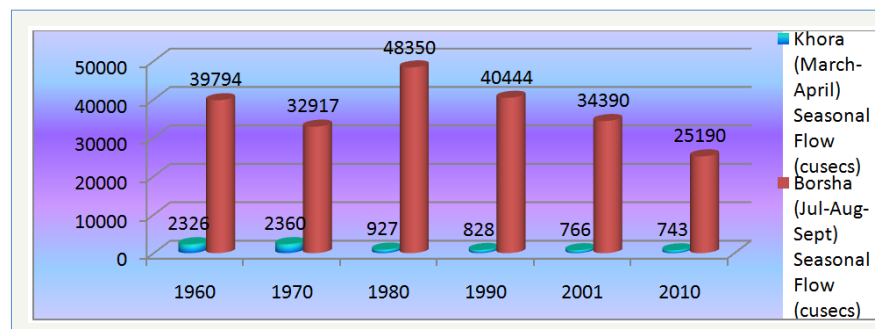

Figure 1: Average flow before and after construction of the Farakka Diversion in 1975 [34].

The government of India has also acted unilaterally in respect to other shared rivers in the region. India plans to divert water from the Brahmaputra Basin in the far western states of the country as part of their National River Linking Project. The two channels that will link the Brahmaputra to the Ganges are the Jogighopa-TeestaFarakka and the Manas-Sonkosh-Teesta-Ganga River [35]. India plans to divert 173 billion cubic meters of water from the link channels to the Indian states of Uttar Pradesh, Madhaya Pradesh, Rajasthan, Maharashtra, Gujarat, Orissa, Andhra Pradesh, Karnataka and Tamil Nadu [36]. The NRLP creates concerns over the portion of Bangladesh not already affected by the Farakka Barrage [37].

\section{Water and Agricultural Development in Bangladesh}

The government in Bangladesh is actively reviewing the relationships among water, land and community. The upstream water withdrawal from the Ganges Basin is one major reason for this review of water development approach in Bangladesh. As McGregor [31] points out, "India has withdrawn vast amounts of water from Farakka without any bilateral agreement. India also has made massive withdrawals at various points further upstream, before the Ganges even reaches Farakka." These withdrawals create major policy challenges for water management in Bangladesh. One major water policy goal of the Gorai River Restoration Project, for instance, is to overcome sedimentation andcharland created by the upstream water withdrawal along the Gorai River. The term "char lands" is used to refer to newly created islands within rivers and extensions of shoreline beyond the boundaries of private property holdings. Agricultural initiatives like, the Gorai-Kobodak project, deep tube well and shallow tube-well projects have also been designed to overcome the effects of charlands and water scarcities. These technological practices in Bangladesh show "how the imperial pretensions of agronomic science-its inability to recognize or incorporate knowledge created outside its paradigm-sharply limited its utility too many cultivators" [38].
The government of Bangladesh has implemented a long series of water and agricultural modernization initiatives since the $1950 \mathrm{~s}$, many of them driven by funding from external donor agencies such as the World Bank. During the Pakistan era, following the Krug Mission Report, a master plan was developed and carried out by the East Pakistan Water and Power Development Authority in 1964 (Thompson and Sultana 1996:1). This master plan called for the construction of embankments for irrigation, flood control and drainage systems. After independence, the Bangladesh Government continued this top-down approach. Bangladesh Water Development Board (BWDB), Bangladesh Agricultural Development Corporation (BADC) and the Local Government and Engineering Department (LGED), developed the Gorai-Kobodak, Pabna Irrigation, MeghnaDhonogoda, Chandpur Irrigation, Dhaka-Narayangonj-Demra dam and Narayanganj-Narshindi projects. These centrally managed projects perfectly illustrate the government's approach to local water resource management. All of these projects transform community based resource management to government and international agencies. This external involvement is helpful for local and international investors, contractors, government officials, and rich farmers, but it causes livelihood challenges for local poor farmers as they rely on local 'common' water resources.

In the 1960s, agricultural development policies seek to secure food availability with green revolution. The Pakistan Government established the Agricultural Development Corporation (ADC) in 1961 to modernize agricultural sectors [39]. After independence, Bangladesh Government continued this approach by establishing the Bangladesh Academy for Rural Development (BARD). BARD promotes research and development of new technologies, including High Yielding Variety (HYV) crops, chemical fertilizers and controlled irrigation for agricultural modernization [40]. For these purposes, BARD got funding from the different agencies such as the Ford Foundation. Nobody in the government and international agencies cares about community understanding of food security based on ecosystem embedded agricultural production and employment opportunities.

Whatever their political differences, all of the governments in Bangladesh, under Mujibur Rahman, Ziaur Rahman, Ershad, Khaleda Zia and now Sheikh Hasina, promoted water and agricultural development based on the international politics of green revolution, charland created by the upstream water withdrawal Structural Adjustment Plan, General Agreement on Tariffs and Trade, Poverty Reduction Strategy Paper and Millennium Development Goals (Table 1) and most recently Sustainable Development Goal. President Mujib promoted government controlled commercial water and agricultural modernization policies supported by foreign aid. Despite this modernization, Bangladesh faced a major economic collapse during Mujib's time in office. Zia government extended the Mujib Regime's modernization approach and promoted the Green Revolution. The government restored local water bodies based on the khal khanon kormochuchi, or canal excavation program for irrigation purposes. President Ershad followed his predecessors and extended further this modernization approach [41]. The Hasina and Khaleda governments always support 
modernization approaches that exclude local voices. In 2013, for example, the Hasina Government signed the Trade and Investment Cooperation Framework Agreement (TICFA), the newest addition to this modernization process that is connected with neoliberal development approach [42].

Table 1: Development programs promoted by international donors in bangladesh.

\begin{tabular}{|c|c|c|}
\hline Periods & Programs & Objectives \\
\hline \multirow[t]{2}{*}{$1950 \mathrm{~s}$} & $\begin{array}{c}\text { Krug Mission and new } \\
\text { water management system } \\
\text { (FCDI) funded by foreign } \\
\text { aid, education and training } \\
\text { programs }\end{array}$ & $\begin{array}{c}\text { Technological approach in } \\
\text { river and water resource } \\
\text { management }\end{array}$ \\
\hline & & $\begin{array}{l}\text { New generation of experts } \\
\text { and skill manpower for } \\
\text { agricultural development }\end{array}$ \\
\hline $1960 s$ & Green Revolution & $\begin{array}{l}\text { Mono-cropping and } \\
\text { market orientation in } \\
\text { agricultural sectors }\end{array}$ \\
\hline $1970 \mathrm{~s}$ & Poverty Alleviation Program & $\begin{array}{l}\text { New institutions and civil } \\
\text { societies compatible with } \\
\text { market economic systems }\end{array}$ \\
\hline $1980 \mathrm{~s}$ & Structural Adjustment Program & $\begin{array}{l}\text { Reviews of water and } \\
\text { agricultural sectors } \\
\text { based on suggestions of } \\
\text { international agencies }\end{array}$ \\
\hline $1990 \mathrm{~s}$ & Globalization & $\begin{array}{l}\text { Remove trade barriers } \\
\text { and promote water and } \\
\text { agricultural technologies }\end{array}$ \\
\hline $2001 \mathrm{~s}$ & $\begin{array}{c}\text { Poverty Reduction Strategy } \\
\text { Paper }\end{array}$ & $\begin{array}{c}\text { Sugar coated Structural } \\
\text { Adjustment Plan }\end{array}$ \\
\hline $2010 s$ & Millennium Development Goals & $\begin{array}{c}\text { Community development } \\
\text { and environmental } \\
\text { sustainability }\end{array}$ \\
\hline
\end{tabular}

Earlier Khaleda Government in 2001-2006 adopted Poverty Reduction Strategy Paper (PRSP) in 2004, based on the idea that poverty could be reduced through introduction of new agricultural technologies. The PRSP began in 1999 as an IMF and World Bank initiative for heavily indebted poor countries, to provide debt relief and to contribute to the creation of a Comprehensive Development Framework for the country. Based on the PRSP guidelines, the World Bank and IMF review every development sector, such as agriculture and water, in Bangladesh to promote macroeconomic development for poverty reduction (Centre for Policy Dialogue n.d.:1). The PRSP recognizes the importance of the environment, water resource management, education, and gender in the agricultural labor market, private sector development and financial sector reform for the achievement of its goals. The central government identified agricultural sectors as a major part of rural development under the five thematic components: rural non-farm sectors, micro-credit for poverty reduction, food security, disaster management and safetynet programs [43].

Thegovernmentalso adopted all of the Millennium Development Goals (MDGs) in 2000 for poverty reduction and development [44]. These goals include: MDG no 1 eradicate extreme poverty and hunger, MDG no 2 achieve universal primary education, MDG no 3 promote gender equality and empower women and MDG no 7 ensure environmental sustainability [45]. These goals are closely linked with PRSP for water and agricultural modernization, which includes NGOs and private sectors, based on a National Plan for Disaster Management (NPDM). Based on the performance review of PRSP, in 2010, the AL government (2008-2013) adopted PRSP-II: Steps towards Change (STC) to achieve the MDG targets. For this purpose, the government has promoted agricultural diversification to include crop sectors and non-crop sectors and subsidized water and agricultural technologies and removed trade barriers [44].

Since the 1980s, the effects of top-down water development approach cause major extreme flooding in 1988, 2007 and 2011. For example, the 1988 flood causes damages and losses of food, housing, field crops and agricultural production materials, which are estimated as USD 1.5 billion (World Bank 1989). After this disastrous flood, the World Bank invested USD 10.1 billion in the Flood Action Plan (FAP) in Bangladesh [46]. The FAP involves massive structural interventions in flood control, drainage and irrigation systems. The Gorai River Restoration Project mentioned above was implemented as part of this FAP.

In 1991, the government has established the Water Resources Planning Organization (WARPO) for developing Integrated Water Resource Management (IWRM) based on the goals of MDG and PRSP. The government has promoted this approach through the Water Resource Planning Act (1992), National Water Policy Act (1999), National Water Management Plan (2001), Guidelines for Participatory Water Management (2000), Bangladesh Water Development Board(BWDB) Act (2000), Coast Zone Policy (2005) and the Water Act (2012) (IMF 2013:309). WARPO and BWDB developed Small Scale Water Resources (SSWR) programs, for example, deep tube-well and shallow tube-well based on the PRSP guidelines [47].

The government has promoted private sector participation with these SSWR programs [48]. For this privatization purpose, the government allocated special budget in every Five-Year Plan based on the PRSP guidelines. The government also provides special allocations for the ministries of agriculture, fisheries and livestock and water resources in the five year plans together with trade liberalization policies [49]. The government argues that "liberalization of industrial and a trade regime in the wake of globalization is likely to have significant effects on Bangladesh's SMEs (Small and Medium Enterprises)." In 2011-15, the government reduces tariff barriers to import water and agricultural technologies like deep tube-wells and fertilizers based on guidelines of the World Trade Organization in the sixth Five Year Plan [50,51]. The major goal was to open local markets for foreign investment in agricultural sectors, in order to achieve the PRSP and MDG goals.

As part of this investment, the government also changed the National Seed Policy (NSP) to prioritize private sectors' seed development, production, import and marketing based on guidelines of the PRSP and MDGs. In this context, the Seed Act of 1977 was revised in 1997 in order to open up scopes for private sector participation. The National Food Policy (NFP) and Country Investment Plan (CIP) were developed to achieve the MDGs. Based 
on this CIP, the government has specified five programs of action: crop, fisheries, livestock, agro-forestry, water management and climate change adaptation [51]. The Ministry of Finance (MoF) has specified fisheries and aquaculture development based on private sector involvement for fisheries management. The government has developed Fish and Livestock Act, the Fish Hatchery Act and Fish and Livestock Feed Act in 2010 for fish feed, production, processing, quality control, export, transportation and marketing. For this purpose, the government has reformed Bangladesh Fishery Research Institute (BFRI) for fish species development.

The government has promoted agricultural research with extended funding for new institutes like Bangladesh Agricultural Research Institute, Bangladesh Rice Research Institute and Bangladesh Institute of Nuclear Agriculture for promoting agricultural modernization like HYV crops. These government agencies have got supports from Holland, the USA, Australia, European Union, Belgium, Denmark and Food and Agricultural Organization (FAO). Again, the government staff from these agencies received training grants from the MDG and PRSP project funds for capacity building [52]. This training and research have extended to genetic modification, tissue culture and biotechnological promotion. This modernization approach was helpful for commercialization of agricultural and agro-processing sectors in Bangladesh. Consequently, agricultural sectors are currently major sources of raw material for Export Processing Zones in Bangladesh that are guided by WTO and GATS agreements [53].

At local level, the government had provided credit opportunities for local farmers to buy plow technologies in place of oxen dependent cropland cultivation. The government, based on neoliberal development approach, included NGOs in implementing credit programs based on the notion of micro-credits. These programs have promoted agricultural diversification based on modernization of fisheries, livestock, HYV crops and agro-forestry [54]. This diversification approach introduced foreign fisheries, new varieties of vegetables, foreign poultries and foreign trees and failed to recognize the importance of local fisheries, local vegetables, domestic animals and local vegetation respectively. The government has trained farmers in this modernization process, which are relevant to Scott's [38] approach to agricultural development. As Scott noted, "market-oriented experiment stations with good yields, great adaptability, and reliability...[are] not just producing crops; they are reproducing farmers and communities with plant breeding skills, flexible strategies, ecological knowledge and considerable self-confidence and autonomy". For this agricultural modernization, the government has reformed Department of Agricultural Extension (DAE), Department of Livestock (DAE) and Department of Fisheries (DoF). The government has also established guidelines for collaborating with NGOs and private companies [51]. Thus all of the programs mentioned in Table 1 was started to implement in Bangladesh since departure of the British in 1947.

\section{Human Rights Concerns Over Chapra People}

In the context of Gorai riverbank people in Chapra, only a secured level of water rights over the Ganges Basin flow can protect their human rights. This water right can secure agricultural production and rights to food, shelter, employment, health care and education. This argument is similar to Beaumont [55]: "in determining vital human needs, special attention is to be paid to providing sufficient water to sustain human life, including both drinking water and water required for production of food in order to prevent starvation". However, when the marginalized basin communities at Chapra fail to get the regular basin flow to produce crops, they encounter violations of the other human rights. The Ganges Basin hydro politics and water development approach are responsible for many of these violations that have some major historical legacies.

The marginalized people of the riverbank in Bangladesh are excluded from water development process since the British regimes. The British in India constructed 2,298 miles of canals for irrigating 1.2 million acres of croplands in 1854 at the upper Gangetic area. Moreover, they constructed the different canals at the lower Ganges area like some canal, Tribeni canal and Sarda canal [56]. Indigenous communities and their historical rights over local natural resources are ignored in these water development activities [57]. On the other hand, the interests of Zamindars including rich farmers are promoted for commercial agricultural production based on this water development approach. After independence of India in 1947, the government of India followed the similar approach that causes further human rights concerns over river bank people in Indian subcontinent.

Water infrastructures like dam create major ecological concerns throughout the basin area. For example, the unilateral Farakka diversion causes major human rights concerns due to major ecological disasters in the Ganges Dependent Area (GDA) people in Bangladesh. The GDA is currently encountering major water right failures as the Ganges Basin flow is continuously decreasing that cause salinity intrusion, char land (newly emerged land in a riverbed) and riverbank erosion. Consequently, many traditional occupational groups like fisher folk at Chapra encounter employment right failures and encountered displacements that also cause housing rights violation. Kafil, a focus group discussant, informed me that he encounters five time displacements from their ancestral homes in three generations due to river bank erosion. Many of his grandfather's croplands are now in the middle of Gorai River. He argued that the previous Chapra village is now char lands and the village has shifted two kilometers west in relation to the previous Gorai River channel. The current river location was their village during his father's generation. Currently, he encounters challenges for crop production due to failures of accessing ecological resources like local crop seed or siltation, which is responsible for his family's food rights violation. In addition to the GDA in Bangladesh affected by the Farakka effects, the rest of Bangladesh encounters new human rights concerns with the NRLP.

Like the government in India, East Pakistan and afterwards independent Bangladesh followed the similar development approach to water resource management, which created further concerns over the human rights of Chapra people. This approach is exposed in Master Plan of East Pakistan Water and Power 
Development Authority (EPWAPDA). During the 1960s in Pakistan regime, the Flood Control, Drainage and Irrigation (FCDI) was established based on Krug Mission's recommendation for coastal embankment and polder system to reduce negative effects of natural disasters like salinity intrusion and to increase agricultural production in southwestern part of Bangladesh. The GangesKobodak (GK) project is one component of this FCDI, which had begun in Pakistan regime and is continued in Bangladesh. Kafil and Sabina, my two FGD respondents, argued that the GK project changed local landscapes including river flow, wetlands and canal, which disconnect linkage between croplands and water bodies. This disconnection is responsible for local environmental degradation and ecological resource reduction, which create employment, food, and health rights concerns. Despite this negative outcome, the project fails to reduce concerns in terms of flood and drainage congestion. On the other hand, this project adds new concerns after the Farakka effects. According to Billal, the GK project not only reduces local ecological resources like cropland siltation but also increases flooding, drought, water stagnation, erosion and salinity intrusion.

After independence of Bangladesh in 1971, EPWAPDA was renamed as Bangladesh Water Development Board (BWDB) and continued the historically established top-down water development approach. The Government exploits technologies for promoting commercial agricultural production, which deprives local marginalized people from local ecological resources. These technologies cause major violations of traditional employment rights that have historical and cultural context. Major examples are green revolution in coordination with appropriate water technologies in Bangladesh. This approach extends market economic systems to grass root communities, which causes major human rights concerns for Chapra people as they depend on wild ecological resources for protecting their livelihoods. According to Jonnar and Alamgir, two focus group respondents, they need to buy goods like fish from market once they were freely available although their income did not increase to secure purchasing power. This market economic domination over the marginalized people creates food rights violations. Again, Flood Action Plan (FAP) fails to recognize community understanding of water resource management and increases these rights concerns for the different groups like traditional farmers, boat drivers, fisher folks and blacksmith

Bakar and Mofiz informed me, during the focus group discussion, that every aspect of their agricultural production is controlled by government and rich farmers. They cannot get water into our croplands unless they desire to do so although we had freedom when river water was available. they need to buy fish and chicken with market price although They had better past. They need to get training from government and other agencies although we had rich local knowledge. These external dominations over local resource management causes major human rights violations that further increase with ecological vulnerabilities and environmental degradations.
Despite the government's major water development efforts like FAP, the UNDP ranked Bangladesh as the fourth most flood vulnerable country of the world. For example, the floods of 1991 and 1998 killed 1700 and 1050 of people respectively [58]. In addition to this death, continuous ecological vulnerabilities and structural domination cause major reasons for human rights violations at Chapra. The 1988 flood causes damages and losses of food, housing, field crops, and agricultural production materials, which are estimated to USD \$ 1.5 billion [59]. Keramot and Laily, two focus group respondents, informed me that rich farmers can overcome these losses as they have alternative resources whereas they encounter major survival challenges as they din ane din khai (live their life from hand to mouth). Rather than advancing their economic wellbeing, the government programs are responsible for an increasing their human rights violations in respect to rights to food, employment, health care, education and housing. Some programs create more harm to human rights at Chapra than resolving their existing livelihood challenges.

In this context, the historically developed water and agricultural development approach threatens the survival of marginalized people at Chapra. Alamgir and Bakar argued that the government is destroying our root of development for serving the interests of the corporate elites. The government agriculture policies introduced chemical fertilizers by excluding ecosystem dependent fertilizers like siltation and algae. The government described local domestic animals negatively to promote foreign poultry and livestock. This development approach is relevant to Scott [38]: "plants that are valued become 'crops,' the species that compete with them are stigmatized as 'weeds,' and the insects that ingest them are stigmatized as "pests". Consequently, Alamgir and Bakar, two focus group respondents, informed me that local fish species are getting extinction. Khan informed us that more than twenty-eight indigenous fish species have become extinct due to interventions such as the Farakka diversion and environmental pollution. Currently, ten percent of 260 local fish species are reported to be encountering survival challenges [60].

In addition to this ecological resource loss, new development approach creates the differential outcomes between the rich and marginalized people at Chapra. This approach is helpful for local and international investors, contractors, government officials and rich farmers but causes survival challenges for local poor farmers as they heavily rely on local ecological resources. For example, the government changed the National Seed Policy (NSP) to prioritize private sectors' commercial, production, import and marketing which promote seed marketing in agricultural production. This market economic approach is also promoted on the other sectors like fisheries, forestry and livestock. Jalil and Abul, two focus group respondents, informed me that introduction of chemical fertilizers and exclusion of ecosystem dependent fertilizers like siltation and algae creates more concerns over their livelihoods. In this process, their crop seeds, fisheries and livestock are replacing with HYV crops, foreign fish and livestock, which create major human rights concerns over the marginalized people at Chapra. 
Some of them try to resolve their concerns with microcredit programs that have mix outcomes. Few of them are successful in overcoming their concerns while most of them encounter new challenges. For example, Billal took BDT 16,000 (USD\$215) from a local NGO and bought two calves. The NGO asked for installment after two weeks of providing the loan although the calves need about one year to be matured for commercial purpose and he did not have enough saving. Due to fodder crises, one cow had died after three months and another cow delivered a after one year and offered two kilograms milk each that is not enough to provide installment.

\section{Conclusion}

The top-down development programs create structural domination over community livelihoods that are responsible for ecosystems destruction, environmental degradation and human rights violations. Chapra communities have their own understanding of maintaining bonds between water and agriculture. However, new water and agricultural development approach since the British regime promotes the transformation of locally embedded understanding of water resource management. (dot after management) This transformation causes marginalization by treating nature and local people as commodities to promote the business interests of corporate elites; Their concerns increase with foreign livestock in place of domestic animals. The government described local domestic animals in such a way that they can promote this foreign poultry and livestock. Numbers of indigenous fish species reduce significantly due to FAP and bio-diversity loss. Moreover, the increasing commoditization of water and agriculture causes human rights concerns over Chapra community. Because of increasing exclusion, social inequality and exploitation from local development projects like the GRRP, the GK project, and Green Revolution, the marginalized groups of people are increasingly encountering these human rights violations. To address these concerns properly, it is important to scale-up local community voices in water and agricultural policy making and implementation processes.

\section{References}

1. Bangladesh Bureau of Statistics (BBS) (2011) Population and housing census 2011. Government of Bangladesh, Dhaka, Bangladesh.

2. Bangladesh Bureau of Statistics (BBS) (2010) Area population household and household characteristics. Government of Bangladesh, Dhaka, Bangladesh.

3. Bangladesh Bureau of Statistics (BBS) (2009) Monitoring the situation of children and women: Multiple Indicator Cluster Survey (MICS) 2009. BBS, Dhaka, Bangladesh.

4. Bangladesh Bureau of Statistics (BBS) (2010) Area Population Household and Household Characteristics. Government of Bangladesh, Dhaka, Bangladesh

5. Khalid I (2010) Bangladesh Water Concern. South Asian Studies 25(1): 73-87.

6. Rahman MA (2012) Consultancy Services for Feasibility Study and Detailed Engineering for Ganges Barrage Project. Ministry of Water Resources, Dhaka.

7. Klawitter S, Qazzaz H (2005) Water as Human Right: The Understanding of Water in the Arab Countries of the Middle East. Water Resources Development 21(2): 253-271.
8. Irujo AE (2007) The Right to Water. Water Resources Development 23(2): 267-283.

9. Donahue JM, Johnston BR (1998) Water, Culture, and Power: Local Struggles in a Global Context. Island Press, Washington, USA, pp. 396.

10. Magdoff F, Foster JB (2010) What Every Environmentalist Needs to Know About Capitalism. Monthly Review 61(10).

11. Blaikie P, Brookfield H (1987) Land Degradation and Society. Methanuem London.

12. Cleveland DA (1998) Balancing On A Planet: Toward An Agricultural Anthropology for the Twenty-First Century. Human Ecology 26(2): 323340 .

13. Latour B (2004) Politics of Nature: How to Bring the Sciences into Democracy, trans. Harvard University Press, Cambridge, London.

14.Das V, Poole D (2004) Anthropology in the Margins of the State. Santa Fe: School of American Research Press 40(1): 140-144.

15.Pels P (1997) The Anthropology of Colonialism: Culture, History, and the Emergence of Western Govern mentality. Annual Review of Anthropology 26: 163-183.

16.Ferguson J (1994) The Anti-Politics Machine: Development, Depoliticization, and Bureaucratic Power in Lesotho. University of Minnesota Press 24(5): 176-181.

17.Parua PK (2010) Necessity of Regional Cooperation. The Ganga 64: 267282.

18.Sarma JN (2005) An Overview of the Brahmaputra River System. In: Singh VP, Sharma N, Ojha CSP (Eds.), The Brahmaputra Basin Water Resources 47: 72-87.

19. Novak JJ (1993) Bangladesh: Reflections on the Water. Bloomington, Indiana University Press, Indiana, USA.

20.Rahaman MM, Varis O (2009) Integrated Water Management of the Brahmaputra Basin: Perspectives and Hope for Regional Development. Natural Resource Forum 33(1): 60-75.

21. Mamun A (2010) Understanding the Value of Local Ecological Knowledge and Practices for Habitat Restoration in Human-altered Floodplain Systems: a Case from Bangladesh. Environmental Management 45: 922 938.

22.Minkin SF, Boyce JK (1994) Net Losses: “Development" Drains the Fisheries of Bangladesh. Amicus Journal 16(3): 382-390.

23. Bhasin S (1996) India-Bangladesh Relations: Documents 1971-94. Siba Exim. Delhi, India.

24. Hill D (2006) The Politics of Water in South Asia. Transforming Cultures eJournal 1(2).

25. Hossen MA (2012) Bilateral Hydro-hegemony in the GangesBrahmaputra Basin. Oriental Geographer 3(53).

26. Rahman MM, Rahman MR, Asaduzzaman M (2010) Establishment of Dams and Embankments on Frontier River of North East Part of India: Impact on North-Western Region of Bangladesh. J Sci Foundation 8(1\&2): 1-12.

27. Nakayama M (1997) Success and Failures of International Organizations in Dealing with International Waters. Water Resources Development 13(3): 367-382.

28.Swain A (1996) Displacing the Conflict: Environmental Destruction in Bangladesh and Ethnic Conflict in India. Journal of Peace Research 33(2): 189-204.

29. Gupta AD, Babel MS, Albert X, Mark O (2005) Water Sector of Bangladesh in the Context of Integrated Water Resources Management: Review. International Journal of Water Resources Development 21(2): 385-398.

30. Islam MR (1987) The Ganges Water Dispute: An Appraisal of a Third Party Settlement. Asian Survey 27(8): 918-934.

31.http://apsa2000.anu.edu.au/confpapers/mcgregor.rtf 
32. Hossain I (1981) Bangladesh-India Relations: Issues and Problems Asian Survey 21(11): 1115-1128.

33. Verghese BG (2006) Water Resources in the Northeast: Development Options in a Cooperative Framework. Background Paper 1. Center for Policy Research, India.

34. Bangladesh Water Development Board (BWDB) (2012) The Ganges Basin Flow Data at the Harding Bridge Station in Bangladesh. Government of Bangladesh. Dhaka: BWDB.

35. Rahaman MM, Varis O (2009) Integrated Water Management of the Brahmaputra Basin: Perspectives and Hope for Regional Development. Natural Resource Forum 33(1): 60-75.

36. Ahmad QK, Ahmed AU (2004) Regional Cooperation on Water and Environment in the Ganges Basin: Bangladesh Perspectives. In The Ganges Water Dispersion: Environmental Effects and Implications. In: Mirza MM (Ed.), Kluwer Academic Publishers, Netherlands, 46: 305-325.

37. Khalequzzaman M (1993) Farrakka Barrage: History, Impact, and Solution. University of Delaware, New Jersey, USA.

38. Scott JC (1998) Seeing Like A State: How Certain Schemes to Improve the Human Condition Have Failed. Yale University Press New, Haven, London.

39. Sobhan R (1981) Bangladesh and the World Economic System: The Crisis of External Dependence. Development and Change 12(3): 327-347.

40. Blair HW (1978) Rural Development, Class Structure and Bureaucracy in Bangladesh. World Development 6(1): 65-82.

41. Seabrook J (2001) Freedom Unfinished-Fundamentalism and Popular Resistance in Bangladesh Today. Zed Books, London \& New York in Association with Proshika, London.

42. Ahsan N (2013) Dhaka Signs TICFA with Washington Today. Dhaka: New Age, Washington, USA.

43. Ministry of Finance and Planning (MoFP) (2005) Unlocking the Potential: National Strategy for Accelerated Poverty Reduction. Government of Bangladesh, Dhaka.

44. International Monetary Fund (IMF) (2013) Bangladesh: Poverty Reduction Strategy Paper (PRSP), IMF, Washington, USA.

45. http://www.un-kampagne.de/fileadmin/downloads/presse/MDGs-ata-Glance-engl-03-2010_02.pdf.
46. Boyce JK (1990) Birth of a Mega Project: Political Economy of Flood Control in Bangladesh. Environmental Management 14(4): 419-428.

47.Water Resources Planning Organization (WARPO) (2009) Annual Report (July 2008-June 2009): Water Resources Planning Organization. Government of Bangladesh. Dhaka.

48.WARPO (Water Resources Planning Organization) (2001) National Water Management Plan. Ministry of Water resources, Dhaka.

49. Ministry of Finance and Planning (MoFP) (2005) Unlocking the Potential: National Strategy for Accelerated Poverty Reduction. Government of Bangladesh, Dhaka.

50.International Monetary Fund (IMF) (2013) Bangladesh: Poverty Reduction Strategy Paper (PRSP). IMF, Washington.

51. Ministry of Agriculture (MoA) (1999) National Agriculture Policy. Government of Bangladesh. Dhaka.

52. Ministry of Food (MoF) (2013) National Food Policy Plan of Action and Country Investment plan Monitoring Report 2013. Government of Bangladesh, Dhaka.

53.International Monetary Fund (IMF) 2013. Bangladesh: Poverty Reduction Strategy Paper (PRSP). IMF, Washington, USA.

54. Ministry of Food (MoF) (2013) National Food Policy Plan of Action and Country Investment plan Monitoring Report 2013. Government of Bangladesh, Dhaka.

55.Beaumont P (2000) The 1997 UN Convention on the Law of Nonnavigational Uses of International Watercourses: Its Strengths and Weakness from a Water Management Perspective and the Need for New Workable Guidelines. Water Resources Development 16(4): 475-495.

56. Khan TR (1996) Managing and Sharing of the Ganges. Natural Resources Journal 36.

57.Verghese BG (1997) Water Conflicts in South Asia. Studies in Conflict and Terrorism 20(2): 185-194.

58.United Nations Development Programme (UNDP) (2004) A Global Report: Reducing Disaster Risk A Challenge for Development. UNDP, New York, USA.

59.http://documents.worldbank.org/curated/en/1998/10/439608/ bangladesh-gorai-river-restoration-project-grrp.

60. Khan AM (2013) The Genie Gave the Money. 